\title{
Difficulties EFL Translation Students face in Translating legal texts into
}

\author{
Arabic \\ Amal.M Alrishan \\ Assistant Prof \\ AlBuraimi University College, Oman \\ دكتورة/ أمل تحمد حسين الريشان \\ الأستاذ المساعد في اللفة الإنجليزية وأساليب تدريسها \\ كلية البريمي الجامعية
}

\begin{abstract}
Undergraduate translation students usually receive training in translating texts of different disciplines such as sciences, law, business, literal, financial, medical, media, etc. Legal texts form a problematic area for EFL undergraduate translation students. This study aimed at investigating the difficulties EFL Translation
\end{abstract}


students face in translating legal texts into Arabic. The participants of the study were 35 undergraduate translation students at Al Buraimi University College in Oman who were selected purposefully. The primary tool of the study was a translation test consisted of a UN text which was submitted to students to detect the difficulties they encounter in translating legal texts. The researcher examined the students' translations who were allowed to use all possible references to help them to handle with the text in classroom. The findings of the study revealed that translation students face major difficulties in translating legal texts into Arabic. These difficulties can be classified as: Problems in the layout of the text, tenor problems, lexical problems, and collocation problems. The researcher attributes the results of the study to the specificity of the translation of legal texts which requires high linguistic and pragmatic competence and professionalism in the field from the part of the translator.

Key Words: Difficulties;EFL; Translation Students; Translating ;legal texts

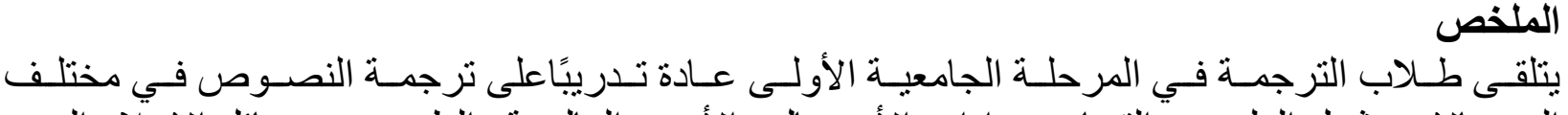

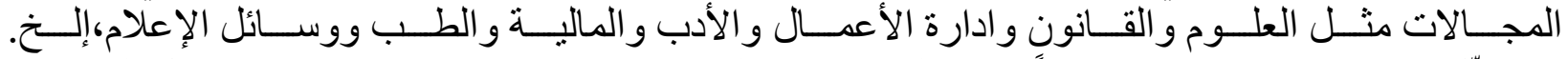

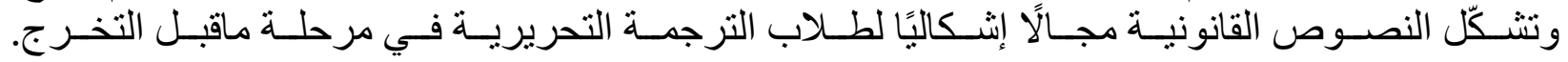

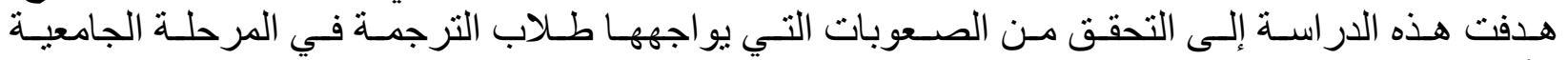

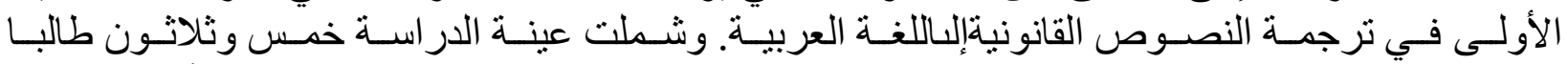

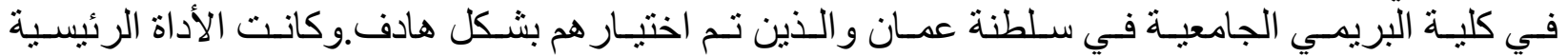

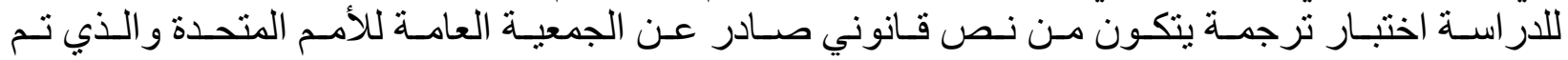

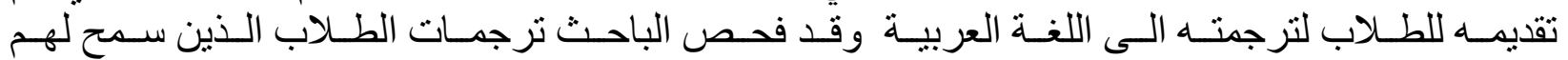

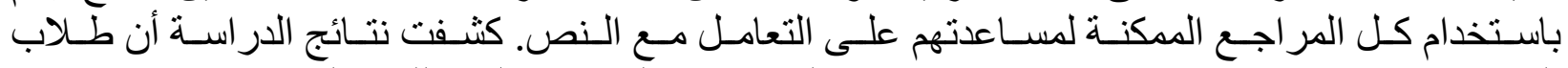

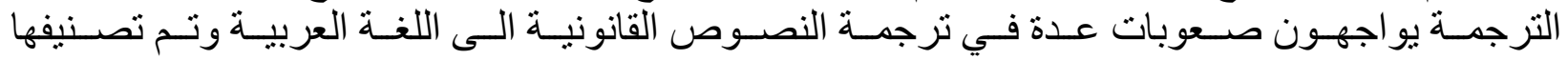

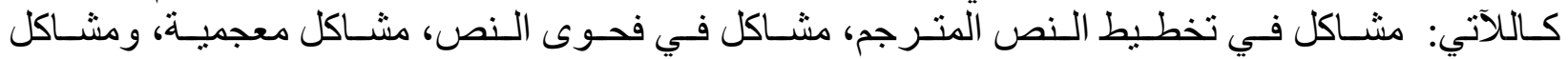




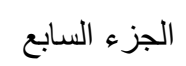

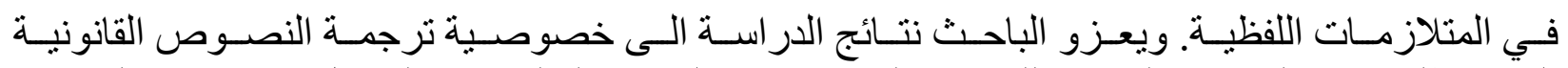

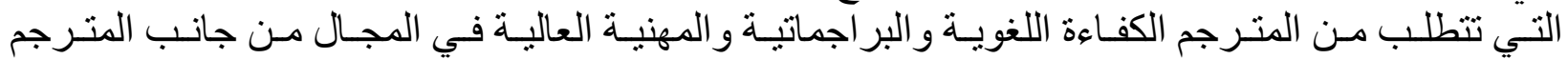
الكلمات المفتاحية: الصعوبات، طلبة اللغة الانجليزية كلغة أجنبية، ترجمة ، النصوص القانونية

\section{Difficulties EFL TranslationStudents face in Translating legal texts into}

\section{Arabic}

\section{Abstract}

Undergraduate translation students usually receive training in translating texts of different disciplines such as sciences, law, business, literal, financial, medical, media, etc. Legal texts form a problematic area for EFL undergraduate translation students. This study aimed at investigating the difficulties EFL Translation 
students face in translating legal texts into Arabic. The participants of the study were 35 undergraduate translation students at Al Buraimi University College in Oman who were selected purposefully. The primary tool of the study was a translation test consisted of a UN text which was submitted to students to detect the difficulties they encounter in translating legal texts. The researcher examined the students' translations who were allowed to use all possible references to help them to handle with the text in classroom. The findings of the study revealed that translation students face major difficulties in translating legal texts into Arabic. These difficulties can be classified as: Problems in the layout of the text, tenor problems, lexical problems, and collocation problems. The researcher attributes the results of the study to the specificity of the translation of legal texts which requires high linguistic and pragmatic competence and professionalism in the field from the part of the translator.

Key Words: Difficulties, EFL Translation Students, Translating legal texts

\section{Introduction}

Legal texts constitute a problematic area for EFL translation students. Translators should possess the required mastery of the linguistic systems of English and Arabic as well as the pragmatic competence. Legal texts are rather problematic and difficult to translate. In translating legal texts from English into Arabic, a translator usually meets some difficulties that are usually hard to overcome. Therefore, it is necessary to tackle these difficulties in order to deal with them. Each discipline in translation has its own jargon and vocabulary that the translator should be acquainted with. Cao (2007, p.10)defines legal translation as "therendering of legal texts from the SL into the TL". Schwarz (1977, p. 21) expresses the notion of 
equivalence and attempts to bring in somelegal consideration, e.g. legal relevance.Newmark (1981, p.47) sees legal translation as a special case withtremendous limitations: "Legal documents require a special type oftranslation, basically because the translator is more restricted thanin any other form." Obenaus (1995, p.249) stresses the link betweenlaw and culture and states that legal documents are "pregnantwith it" (i.e. with culture). White(1990, p.252) states that we "can't experience the original from culture. It is read by one individual,translated by one elseof us spa".Rotman (1995-1996) indicates that legal translation requires precision and certainty. Yet, it uses abstractions whose meanings are derived from particular changing cultural and social contexts.

Such contexts include a certain degree of ambiguity, which increases whenthe legal cultures and systems are vastly different from eachother.Šarčević $(1997$, p.5) claims that "a theory for thetranslation of legal texts must take account of legal considerations", while "it cannot disregard basic issues of translation theory". She alsorefers to the significance of pragmatic considerations in legaltranslation in deciding on an appropriate translation strategy.

Translators of legal texts come across many difficulties since the legal texts are characterized by their specific system.One of the importanthindrancesthat translators come across with is translation of legal terminology. The translation of legal texts requires expertise in the terms and vocabulary related to the field as well as a mastery of both languages English and Arabic.Crystal and Davy( 1969) view that legal translation as a type of technical translation which is characterized by specific features. They classified those features as: layout in which much attention is paid to the parts of the documents which are essential to meaning. Second feature is the grammatical characteristics related to the constructions and the careful interplay between precise and flexible terminology in vocabulary.Last, the legal register's preservation at all levels of forms.Newmark (1982, p.47) sees that there is a difference between the translation of legal documents for information purposes and those which are "concurrently valid in the TL [target language] community." Concerning "foreign laws, wills, and convincing" translated for information purpose only. He added that literal or semantic translation, as he referred to it, is necessary. On the other hand, He emphasized that "the formal register of the TL must be respected in dealing with documents that are to be concurrently valid in the TL community." According to him, these types of translations require the communicative approach that is target language-oriented. In this regard, he recognized that the status of a legal text is instrumental in determining its use in practice.Halliday(1978) argues that register can be specified in terms of field, mode, and tenor.Its form represented by syntax, layout, and tenor. 
Accordingly, the translation of legal texts requires expertise in the related field along with the language competence. This expertise includes knowledge of both content and form. Lack of content and form knowledge would, in turn, results in poor translationlack of professionalism and precision.

\section{Literature Review}

Farghal and Shunnaq(1992) conducted a study in which they aimed at investigating the problems postgraduate translation students encounter in translating legal texts. They submitted a UN text to 13 MA translation students at Yarmouk University.The researchers ended with three main problematic areas that the examinees faced: syntax, tenor, and layout. The researchers concluded that Arab translation students face problems when they translate legal texts when it comes to handling syntactic discontinuity in the translated material. Also, the researchers noted that most of the examinees were not aware of the layout features of the text in addition to the tenor problems in their lexical choice. Based on thesefindings, the researchers recommended translation training programs for the students to make students aware of the main characteristics of the legal texts.

Abu-Ghazal (1996) conducted a study in which he sought to define the linguistic and translation problems translators come across in general and EFL MA students in particular. To do so, he analyzed graduate students' translations at Yarmouk University of a number of UN resolutions. The researcher outlined a number of syntactic and semantic difficulties in legal translation from English into Arabic. He concluded that students should achieve intensive training in legal translation field before practicing it as a career.

Mohammad, Alawi and Fakhouri(2009) aimed at demonstrating the significance of functional and pragmatic aspects in legal translation. They asked three professional translators to translate a real-state contract. The researchers indicated that the most noticed area of difficulty students came across is their unfamiliarity with the characteristic features of the vocabulary in the legal field.

Mohammad,Alawi, and Fakhouri (2010) conducted a study in which they aimed to explore the significance of functional and pragmatic features in legal translation. They sought to explore the relevance of Vermeer's Skopos theory to the translation of contracts through a small pilot study. To do so, the researchers submitted a Real State contracts to be translated by three professional translators. Also, they assigned a group of graduate translation students to translate and professional translators were assigned to translate a "power of attorney" legal text from English into Arabic. The findings of the study revealed that the major problematic area translators came across is their unfamiliarity with the characteristic features of contracts and the difficulty of rendering them into another language. 
AlShehab(2013) aimed at examining the translatability of Google Translation (GT) for a test of six English legal articles or sentences into Arabic. These articles were entered into Google to be translated into Arabic. Qualitative analysis investigated the translatability of GT for sentences compared to human translation. The analysis of Google translation showed that translation for English legal sentences into Arabic is good with the level of partial equivalent. It poses a number of problems in translating the archaic English terms, in dealing with passive voice, and, as previously mentioned, in translating the modal shall. Although GT performance is never likely to reach the level of professionals, it can provide a quick translation for English-Arabic languages. In light of the findings, the researcher set up a number of recommendations for further research.

Faris and Shahu(2013) studied EFL Iraqi students' difficulties in translating legal collocations into Arabic. Their study focused on the committed errors by translation students. To do so, they submitted 15 sentences including collocations to be translated by 20 fourth year college students. They submitted a test that constitutes 15 sentences which contain legal collocations. The results of the study revealed that $70 \%$ of students come across difficulties when translating the collocations from English into Arabic. These difficulties can be classified into three major areas: overgeneralization, the variability of collocations, and the cultural-based idiomatic collocations. The researchers attributed the students' committed errors in translation to the existing cultural differences between the two languages and the failure of the students to provide the equivalent collocation.

El-Farahaty (2016) conducted a study in which he investigated the legal difficulties in translating legal texts between English and Arabic and the procedures that should be followed by EFL translators in their translation. He investigated a number of legal texts. He found that the areas are observed in the different used terms in the two languages.

Al Buwaheid, Hamza,Hajimmaming, and AlKhawaja(2017) conducted a study that investigated the use of collocations in contract agreement and their process of translation by students from Arabic into English. For this purpose, the researchers submitted a test to 35 translation students with collocations to be translated by 35 EFL Iraqi undergraduate translator-students to identify the areas of weaknesses and strengths in their translation. The findings of the study indicatedthat these students had significant problems in translating legal collocations since they lack the linguistic and pragmatic knowledge and awareness the translators need to meet the legal meaning and effect of the translated texts. The study, also, revealed that students are not able to differentiate among the three types of legal collocations, purely technical, semi-technical, and everyday vocabulary collocations. Bases on these results, the researchers recommended more legal translation practices to 
achieve the required level of experience in practicing legal translation that prepare them to the job market.

\section{Methodology}

The study in hand is a descriptive one which aims at investigating the main difficulties EFL translation students encounter in translating legal texts at AlBuraimi University College in Oman. The participants of the study who were selected purposefully are 35 undergraduate translation students at AlBuraimi University College in Oman enrolled in the translation program for the academic year 2016/2017 and who passed at least 6 semesters in the translation program. The primary tool used in this qualitative research is a translation test of UN legal document (see appendix A). They were allowed to use multiple references in translating the text.

\section{Results}

After examining the students' translation versions, it has been noticed that the problematic areas students face in translating the text are fallen into four categories: lay-out problems, tenor problems, lexical and,collocation problems. Below is a discussion of each problem supported by illustrations of the students' translation of the UN text followed by the appropriate translation .

\subsection{Layout}

Layout of the text refers to the plan or the sketch of the text physical appearance. This includes indentation, paragraphing,graphiticchoices; underlining and bold typing. It is concerned withthe process related to the choice of text characters, font, and page specification features in thelines of the page in the suitable way that suits the type of text dealing with.Graphitic is a branch of linguistics related to the properties of shapes used in writing. Indentation is concerned with formatting the paragraphs in the text using the suitable distances and blank space to separate a paragraph from the right or left margins.

In translating legal documents, the layout features are of great importance because they have significant functions in translation. Thus their misuse in translating the text might affect fundamental issues in the texts which, in turn, results in poor translation. Features of layout are used in English and they carry on functions for their use. Arabic, on the other hand has no such features that affect the quality or the core of the translated texts. In English, we use capitalization to write the proper names, names of institutions, organizations, people, and places, but Arabic has no capitalization features. English uses bold typing to illustrate the subject matter. Although this can't be achieved in Arabic handwriting, we normally underline the subject matter in bold to emphasize its importance the thing that all students failed to achieve. Consider the following illustration:

The General Assembly, 
Having considered the recommendation of the economic and Social Council contained in its resolution 1861(56) of 16 May 1974,

Expressing its deep concern over the suffering of women and children belonging to the civilian population who in period of emergency and armed conflict in the struggle for peace, ...

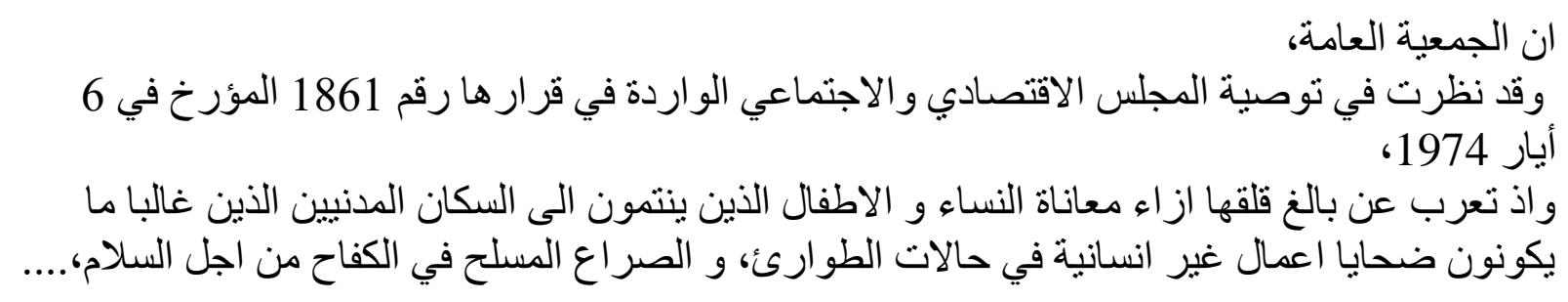

Looking at the above translation, we notice that the translator failed to emphasize the subject matter The General Assembly and Having considered. All students translated the text without paying attention to italics expressions in it. These items are italicized in the legal text to emphasize their important, yet none of the students used underlining to emphasize their importance.

Another existing layout feature that affects the translation of a text is the use of punctuation. The text submitted to students, for example is a one single long sentence with only one full stop at the end of it. Splitting up this long sentence into many sentences in rendering the text into the target language affects the linguistic information and the coherence of the target text. Many students faced a problem in rendering the single sentence keeping the layout without splitting it into a number of sentences, and they didn't even pay attention to the importance of this matter and its effect on the receiver.

To illustrate the point, consider the following examples which illustrate the erroneous rendering by most of the students:

The General Assembly,

Having considered the recommendation of the economic and Social Council contained in its resolution 1861(56) of 16 May 1974,

Expressing its deep concern over the suffering of women and children belonging to the civilian population who in period of emergency and armed conflict in the struggle for peace...

الجمعية العامة وقد نظرت في توصية المجلس الاقتصادي والاجتماعي الواردة في قرارها رقم(1861)

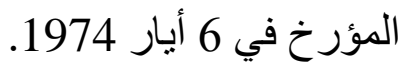

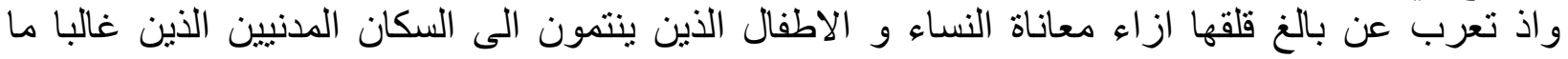

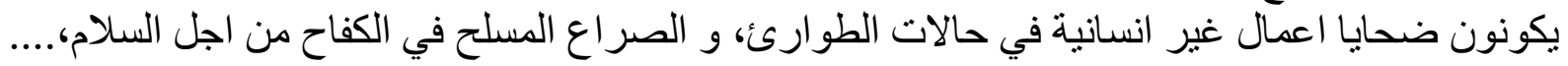


Considering the above illustration, we notice that the examineesplit the long sentence into many sentences in the target language, the matter that affected the cohesion as well as the coherence of the text. Since students are unaware of this important feature, 25 out of 35 used many full stops in their translations splitting up the texts into many separate sentences and paragraphs ending with a full stop. This in turn, interrupts the structural and the semantic flow of the text. They replaced the comma by a full stop which affected the flow and the cohesion of the text.

Another point to be considered here is that the majority of students failed to emphasize the subject matter in the text .As we know English depends on the bold typing and italicization to emphasize the subject matter. None of the students realizes the importance of this emphasis in the translated text. In Arabic, we normally emphasize the subject matter by underlying it in the text since Arabic doesn't follow such system of italicization or capitalization. None of the students recognizes the italics expressions in the source text and the rendered them as normal ones without underlying. This in turn, affects the text.

Observe the appropriate rendering of the above text:

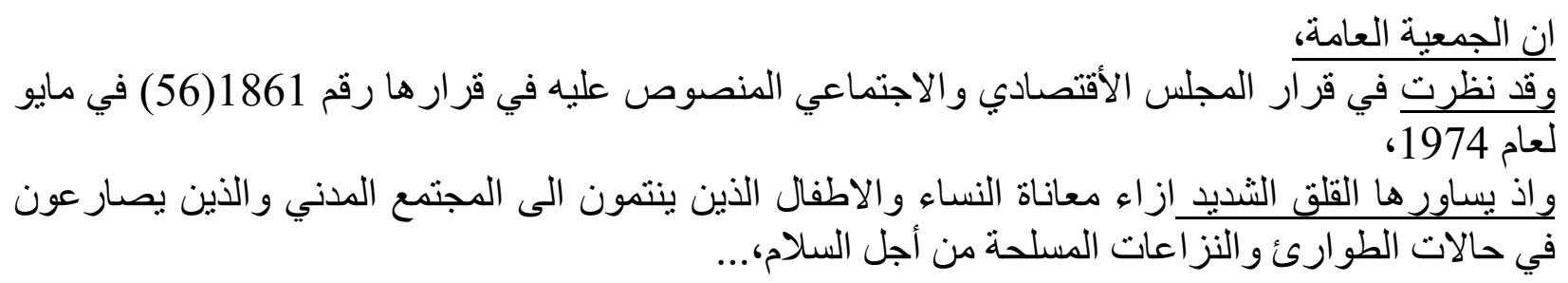

Considering the above translation, we notice that it preserves all the layout features; punctuation, indentation, and italics which is the layout equivalence in the target text. Hence, when students translate a legal document from English into Arabic, they are not aware of the importance of this feature to the flow and smoothness of the text, which might lead to poor, incomprehensible version in translation of the legal text which normally requires high quality, competence and professionalism from the part of the translators.

\subsection{Tenor}

Tenor is one of the three aspects relevant to defining register. The other two aspects are field and mode. (Halliday 1989, p.44)sees register as the specific lexical and grammatical choices made by speakers depending on the situational context, the participants of a conversation and the function of the language in the discourse. Thus, it is concerned with the degree of formality of language. There are three aspects of the context which are known as field, tenor and mode. Field refers 
to the subject matter or content of the text in hand.. Mode is defined as the channel (such as writing, or video-conference) of the communication between the producer and the recipient of the text. This channel might be writing, audio, or video. In linguistics, register can be defined in terms of a number of factors; these factors include context, social occasion, the purpose, and the audience. The termregister can also refer to degrees of formality in language.Halliday's description of register as 'a variety of language, corresponding to a variety of situation', with situation interpreted 'by means of a conceptual framework using the terms "field", "tenor" and "mode" (Halliday, 1985/89: 29, 38). He sees register as a semantic phenomenon in the sense that 'register is the clustering of semantic features according to situation type' (Halliday, 1978,pp. 68, 111, 123)

Haliday and Hasan(1985, p.29) indicate that tenor is one of the three aspects defining register.They indicated that the term tenor refers to the relation between the text producer and receiver at the level of formality viz colloquial, standard, formal, highly formal, etc. Legal texts are characterized by their formal styles at the linguistic level in both English and Arabic. Tenor thus is related to the lexical choice. This formality is related to all word classes; verbs, adjectives, nouns, etc. Holliday's defines the term tenor as 'the cluster of socially meaningful participant relationships, both permanent attributes and relationships that are specific to the situation, including the speech roles' (Halliday, 1978, p. 143)

In translating the legal text by students and after having a look at their translations, we consider the following examples of the students' versions to illustrate the problem in lexical choice for highly formal terms.

$S L$

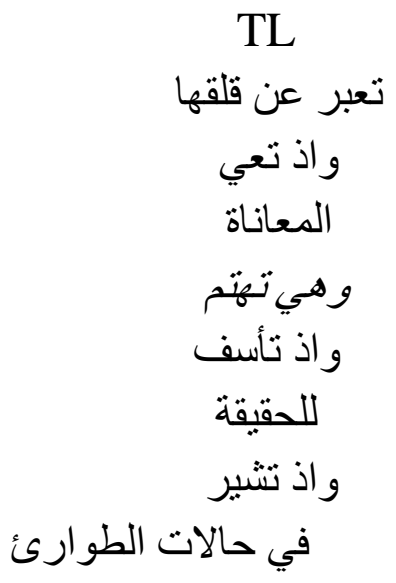


Tabl1 1: Frequencies and Percentages of the Students' Translations according to their case: Appropriate/Inappropriate in Light of Tenor.

\begin{tabular}{|l|l|l|l|l|l|}
\hline SL & $\begin{array}{l}\text { Appropriat } \\
\text { e } \\
\text { Translatio } \\
\mathbf{n}\end{array}$ & $\begin{array}{l}\text { Percentage } \\
\text { s } r \\
\text { Appropriat } \\
\text { e }\end{array}$ & $\begin{array}{l}\text { Inappropriat } \\
\text { e } \\
\text { Translation }\end{array}$ & $\begin{array}{l}\text { Percentages } \\
\text { of } \\
\text { Inappropriat } \\
\text { e } \\
\text { Translation }\end{array}$ & $\begin{array}{l}\text { Totalin } \\
\text { percentag } \\
\text { e }\end{array}$ \\
\hline $\begin{array}{l}\text { Expressin } \\
\text { g its deep } \\
\text { concern }\end{array}$ & 15 & & 25 & 28.6 & $100 \%$ \\
\hline $\begin{array}{l}\text { Aware of } \\
\text { the } \\
\text { suffering }\end{array}$ & 15 & $57.1 \%$ & 20 & $42.9 \%$ & $100 \%$ \\
\hline $\begin{array}{l}\text { Deeply } \\
\text { concerne } \\
\text { d }\end{array}$ & 10 & $28.5 \%$ & 25 & $71.5 \%$ & $100 \%$ \\
\hline $\begin{array}{l}\text { Deploring } \\
\text { the fact }\end{array}$ & 15 & & & & $100 \%$ \\
\hline Recalling & 15 & $57.1 \%$ & 20 & $42.9 \%$ & $100 \%$ \\
\hline
\end{tabular}




\begin{tabular}{|l|l|l|l|l|l|}
\hline $\begin{array}{l}\text { In } \\
\text { emergenc } \\
y\end{array}$ & 26 & $74.2 \%$ & 9 & $25.26 \%$ & $100 \%$ \\
\hline
\end{tabular}

Considering the above illustrations, the majority of students rendered the above highly formal legal terms with less formal ones in Arabic, the matter which affect the formality standard characterizing the legal English text. 25 students out of 35 rendered the highly formal expression Expressing its deep concern with less formal onesتعبر عن قلقها/ تقلق/ تشعر بالقلق. Also, 20 students out of 35 rendered the highly formed expression aware of the suffering with less formal verb. Also, 22 of the students rendered the formal expression aware of thesufferings تعي المعاناة/ تعرف

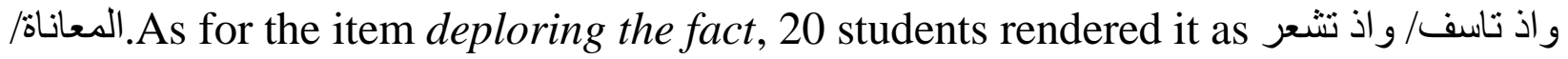
As for the item in emergency, 26 students translated it as:في حالة الطوارئ في expression deeply concerned, 25 of the translators opt to translate it as تهنم بشدة. For the expression Deploring the fact, 23 of them translated it into تأسف للحقيقة. This highly formal expression should be translated as واذ تعرب عن استيائها.

Consider the following highly formal translation of the above expressions respectively:

$S L$

Expressing its deep

concern

Aware of the suffering

Deeply concerned

Deploring the fact

Recalling

In emergency
TL

$$
\text { واذ يساور ها القلق الثديد }
$$$$
\text { و واذ تدرك المعاناة }
$$$$
\text { واذ نشعر بقبق عميق }
$$$$
\text { و واذ تعرب عن استيائها }
$$

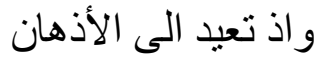

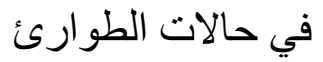

The failure of translation students in rendering the highly formal expressions with highly formal equivalent ones doesn't necessarily affect the content of the text, rather it affects the tenor; the level of formality, highly formal, standard, colloquial use of terms in the target text, which affects the level of professionalism, and precision of the text.

\section{3Collocation problems}


Collocations are defined as the combination of two or more word that often come together.Legal collocations can be classified into three main types: are of three main categories: purely-technical, semi-technical, and everyday collocations. Translation students face problems when they can't differentiate between those categories. The difficulty arises from the fact that students need to use the suitable type of collocation according to the text to be rendered. Lack of knowledge and unawareness of these categories lead to confusion and the misuse of the proper equivalent.

Harvey (2002, p.177) writes that the process of translating legal collocations involves "combining the inventiveness of literary translationwith the terminological precision of technical translation".Alcaraz and Hughes (2014) indicatethat purely-technical collocations are the expressions found in legal contracts and don't exist out this boundary in the same meaning since these collocations carry on a fixed meaning in contracts. Hence, they are essential in translating the context. Šarčević $(1997$, p. 71$)$ stresses that translators should be aware of the two types of parallel legal texts: the first one should be "equal in meaning" and the second one should be "equal in effect". She continued that this awareness requires the translator to "to produce a text that will lead to same legal effects in practice". Shewrites that "basic unit of legal translation is the text, not the word". Accordingly, we think that equivalency in translating legal texts is highly demanded and should reflect the translated text. As for Semi-technical collocations, we can define them as the words and phrases that we borrow from everyday use or from other fields to be used in legal contexts. The selection of the suitable legal collocation to be used in a text is not easy for the translator since he/she is subject to select from a large variety of selections. According to (Mohammad et al 2010, Šarčević, 1997), the selection of the equivalent for everyday collocations depends on contextual and pragmatic considerations. These include the meaning of the original text and other stylistic and contextual limitations.

The difficulty, hence, arises from the fact that students need to use the suitable type of collocation according to the text to be rendered.Lack of knowledge and unawareness of these categories lead to confusion and the misuse of the proper equivalent. Thus, if students of translation don't have the pragmatic and linguistic knowledge and repertoire to be able to provide the equivalent collocation in target language text. To illustrate the translation students struggle to translate the collocation from English into Arabic, consider the following translations of some of them. 
Heavy losses

Strict observance

Important role

Violate law

Conscious

responsibility

Incalculable suffering

Alien domination

Drafting a declaration

Violate law

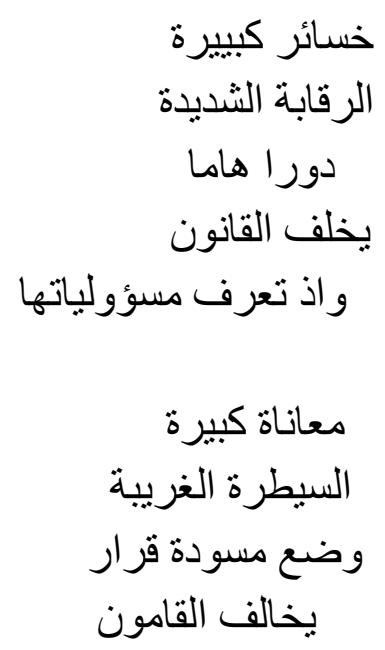

خسائر كبييرة

الرقابة الثديدة

دور الماما

of its

its

يخال الفامورن

Considering the students' translations of the aforementioned collocations, it is noted that the students have difficulty in translating these collocations into their equivalent in Arabic. Nearly 30 students out of 35 failed to render the legal effect of the collocation heavy losses. They rendered it into خسائر كبيرة These translations gives the meaning of the collocation, but don't carry on the legal identical equivalent used in translating legal texts. As for the collocationalien domination, 28 students out of 35 rendered it into السيطرة الغريبة. Despite the fact that students provided the meaning, yet they failed to provide the legal functional equivalent which is الهيمنة الأجنبية. Those students who used the right equivalent for the word domination, failed to give the functional equivalent of the word Alien. In translating the legal collocation strict observance, 23 studentsrendered it into الرقابة

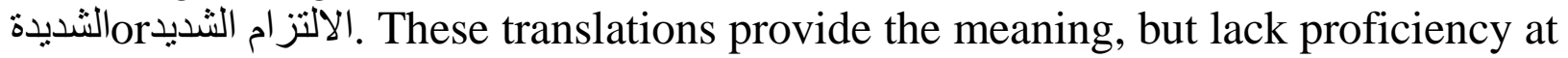
the linguisticand pragmatic levels. In translating the collocationdrafting $a$ declaration, 30 students rendered it into وضع/ طرح مسودة قرار. Although they provided the meaning, they failed to provide the equivalent functional equivalent صياغة مسودة قرار.As for the collocation incalculable suffering, 23 of the student rendered it into معاناة كثيرة/ معانة لا حدود لها/ معاناة عديدة. With regard to the translation of the collocation conscious of its responsibility, 20 students out of 35 translated it as تفهم sسؤولياتها/ تعرف مسؤولياتها/ تدرك مسؤولياتها. Concerning the collocation, violate law, almost all students failed to provide the functional and identical equivalent of this collocation rendering it into يخالف القانون/ يتعدى على القانون يتجاوز القانون/يتعدى على القانون Yet, almost all students rendered the collocation play an important role into يلعب دور الهارنا

Considering the students' aforementioned translations, one can realize that although students successfully translated the everyday life collocations such as 
important role, yet the majority of them failed to provide the functional as well as the pragmatic equivalents of the technical ones. These collocations may carry different meanings if they occur outside the context.In this regards, (Harvey, 2002, p. 177) claims that in translating legal collocation, there is a combination between the literally translation and the terminological precision of technical translation.

Table: The Frequencies and Percentages of the Students' Translations According to their Case: Appropriate/Inappropriate

SL

Appropriate percentages Inappropriate percentages Total Trans

Trans

\begin{tabular}{|c|c|c|c|c|}
\hline Heavy losses & 5 & $14.2 \%$ & 30 & $85.8 \%$ \\
\hline $\begin{array}{l}\text { Alien } \\
\text { domination }\end{array}$ & 7 & $2 \%$ & 28 & $98 \%$ \\
\hline $\begin{array}{l}\text { Drafting a } \\
\text { declaration }\end{array}$ & 30 & $85.7 \%$ & $14.3 \%$ & \\
\hline $\begin{array}{l}\text { Strict } \\
\text { observance }\end{array}$ & 12 & $34.2 \%$ & 23 & $67.8 \%$ \\
\hline $\begin{array}{l}\text { Incalculable } \\
\text { suffering }\end{array}$ & 12 & $34 \%$ & 23 & $67.8 \%$ \\
\hline Violate law & 0 & $0 \%$ & 35 & $100 \%$ \\
\hline $\begin{array}{l}\text { Important } \\
\text { role }\end{array}$ & 35 & $100 \%$ & 0 & $0 \%$ \\
\hline $\begin{array}{l}\text { Conscious of } 1 \\
\text { its }\end{array}$ & 15 & $42.8 \%$ & 20 & $57.2 \%$ \\
\hline
\end{tabular}

responsibility

To appreciate collocations failure, observe the appropriate rendering of the aforementioned collocations respectively:

SL

Heavy losses

Alien domination

Strict observance

Drafting a declaration

Incalculable suffering
TL

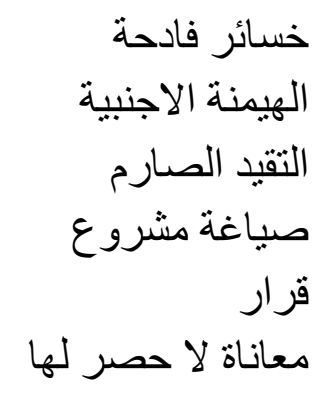


Violate law

Important role

Conscious of its

يخترق القانون

دورا هاما لئان

ت تعي مسؤوليتها

responsibility

\subsection{Lexical Difficulties}

Translators normally come across difficulties in providing the appropriate equivalent terms in translating legal text.Wills (1994, p. 38) indicates that "Many aspects of translation, in particular in the field of LSP, transcend cultural boundaries andare, in some sense, universal. Simplifying somewhat, translation can be depicted as a domainof socioculturally determined linguistic behavior with both culture-specific and universalcomponents".

Šarčević(1997, p. 232) argues that legal translation tends to involve more culturespecific than universal components compared to other types of translation, such as medicine, science or technology..Sager (1998, p.261) sees that such terms "refer to discreteconceptual entities, properties, activities or relations which constitute the knowledge space of a particular subject field".

Langacker (2000, p.4) indicates that a lexical item identifies conceptions and conceptual systems in a flexible way.Langacker $(1988$, p. 51) claims that polysemy is "a frequently used expression typically displays anetwork of interrelated senses". In the monolingual dictionaries of law we notice that these dictionaries offer the definitions of the legal terms in a conceptual network. The translators may use these definitions as included in an entry. Among these dictionaries are Oxford Essential Dictionary of Legal Words and Longman Dictionary of Law.

(Bergenholtz andNielsen indicate that brief definitions are suitable for a translator who "is in doubt as to themeaning of a particular term or combination of terms and wants his opinion confirmed" but not ifthe translator "lacks systematic knowledge'. Looking at the bilingual dictionaries, one can see that they don't provide no enough details on the translation of terms. Thus, translators find it tough to select among those provided terms of polysemous terms if they lack the differences between the provided equivalents especially if they do not own the required ability to recognize the degree of congruity to the SL concept limited degree of detail and contains a mere litany of words without any information on thedifferences between such equivalents. Language for special purposes dictionaries normally provide decontextualized and without collocations and examples of use. Furthermore, the lack of the translator's sufficient knowledge to 
choose the appropriate equivalent of the given terms constitutes another problem for the translators.

In their translation,translation students tend to heavily depend on bilingual dictionaries to detect the equivalent meanings of the lexical items existent in the legal text. This procedure which students find fundamental to explore the meanings of legal terms takes a lot of time from their part. Students might find the equivalent and might not according to the dictionary they use whether it is a technical legal one or a general dictionary that provides lists of equivalents for one term.In this case, students find themselves in a dilemma with suitable equivalent to use. If students don't have the necessary background knowledge in this technical field to select the appropriate equivalent, then they would fail to provide the appropriate required term in the field and their use of the dictionary would be useless in helping them solve the lexical problem they encounter. To clarify students' struggling to find the appropriate lexical terms, consider the following examples from students' translation of the legal UN document:

SL

Subject to suppression

Unequivocal

condemnation

Cruelly suppressing

Powers

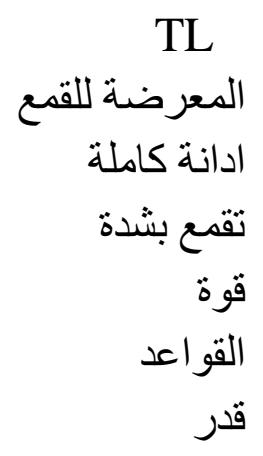

Provisions

Destiny

Considering the above illustration of students 'translations, we notice that students struggle to find the appropriate equivalent terms that suit the technical legal ones in the text which is characterized by highly formal use of legal terms. Take as a sample the legal term unequivocal which is rendered by most students as كاملة/ تامة Almost all students failed to provide the precise legal term كيس لبها لبها students out of 35 didn't provide the appropriate use of this term. In translating the term powers into Arabic, 25 students selected the term äto render it. Despite the fact that this selection doesn't affect the meaning of the text, yet it fails to provide the legal effect. Also, 32 students out of 35 failed to select the equivalent legal term for the term provisions. They rendered it as قو انين/ قو اعد. These translations are used in legal translation, but they are not the functional ones in the text context which demands highly formal legal equivalent as أحكام.In translating the legal term destiny, 28 students out of 35 opt to translate it into قafailing to find the appropriate translation using the equivalent sصيرto suit the formal characteristic of 
the UN legal text. A s for the expression subject to suppression, 25 students out of 30 translated it as المعرضة للقعع , while 30 students out of 35 translated the expression cruelly suppressing as الادانة الكاملة.

The following table demonstrates the frequencies and percentages of students' translations according to their appropriateness:

SL

Appropria Percentage Inappropria Percentages Totalin

te Trans

s of te Trans

Appropria

te Trans

Unequivoc 0

$0 \%$

35

of inappropria $\mathrm{e}$

al

Cruelly

$14.2 \%$

30

te Trans

suppressin

$g$

Subject to 25

$71.4 \%$

10

$100 \%$

Percentag

suppressio

$\mathrm{n}$

$\begin{array}{llllll}\text { Destiny } & 7 & 20 \% & 28 & 80 \% & 100 \% \\ \text { Powers } & 7 & 20 \% & 28 & 80 \% & 100 \% \\ \text { Provisions } & 3 & 0.85 \% & 32 & 99.15 \% & 100 \%\end{array}$

To illustrate the appropriate translation of the above expressions, consider the following:

SL

Subject to suppression

Unequivocal

condemnation

Cruelly suppressing

Powers

Provisions

Destiny
TL

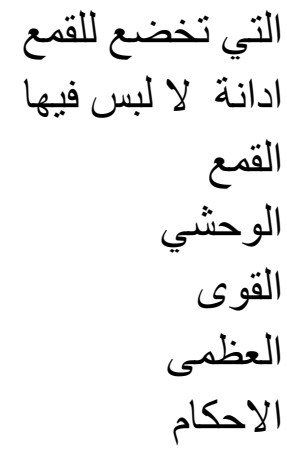

مصبر

Hence, it appears from this that students struggle to find the appropriate equivalent for the legal contextualized terms in the text. Dictionaries that students use to help them finding the equivalent meaning might contain long lists of equivalents, yet it is the students' responsibility to choose the appropriate precise term that serves the 
text. Since bilingual dictionaries provide decontextualized equivalents for the terms, most students failed to select the appropriate term to contextualize it with reference to the nature and topic of the text. This can be attributed to the weak background knowledge and insufficient awareness of the translators of legal texts. Translating legal texts demand professionalism, precision in selecting the lexical terms, as well as sufficient linguistic and pragmatic knowledge in the legal field. If these demands are not met, the using the dictionary would be just a matter of timewaste for the translators.

\section{Conclusion}

Considering the results above and examining the samples of students' translations in this paper, we can conclude that EFL translation students face difficulties in translating legal texts into Arabic. These difficulties can be categorized into four main areas: layout, tenor, collocations, and lexical terms. Despite the fact that students were able to provide the meaning of the text, still, the majority of them failed to provide the professional, linguistic, precise technical equivalents which characterize the legal texts. Furthermore, students lack professionalism in translating legal collocations. The matter that lead to poor translation at the tenor level since students lack the competency in rendering the highly formal legal terms into their formal equivalent in Arabic. Students tended to use literal translation or paraphrasing in translating them since they lack familiarity with terminology of legal texts. Thisleads to loss of legal effect of the legal text. The researcher attributes these findings to the lack of professionalism and training from the part of the students, the students' unfamiliarity with the legal collocations in both the source and the target language and the lack of training in translating legal texts, competency, and the poor mastery of the linguistic system in both languages. Thus, the researcher recommends the use of more specialized training courses in legal translation to enhance their competency in translating legal texts and to raise their familiarity with the technical terms and collocations and to improve their linguistic and pragmatic knowledge 


\section{References}

Abu-Ghazala,Q. (1996). Major Problems in Legal Translation.M.A Thesis, Yarmouk University, Irbid, Jordan.

Al-Buwaheid, M; Hamza, Z; Hajmamming, p; and AlKhawaja, H.(2017). Translating Legal Collocations in Contract Agreement By Iraqi EFL StudentsTranslators. International Journal of Education and Literary Studies, 5( 1), pp.5568.

Alcaraz, E., Hughes, B. (2014). Legal translation explained. London: Routledge.

AlShehab, M.(2013). The Translatability of English Legal Sentences into Arabic by Using GooglTranalation.International Journal of English Language and Linguistics Research, 1 (3), pp.18-31.

Bahti, V. ( 1983). An Applied Discourse Analysis of English Legistlative Writing. University of Aston: Birmingham.

Bergenholtz, H. (2002). Terms in the Language of Culture-Dependent LSP Dictionaries.Lexicographica, 18, pp. 5-18. 
Cao, D.(2007). Translating Law.Clevedon : Multilingual Matters Ltd.

Crystal, D and Davy,D . (1969). Investigating English Style. London: Longman.

El-Farahaty, H. (2016). Translating Lexical Legal Terms Between English and Arabic. International Journal for the Semiotics of Law - Revue internationale de Sémiotiquejuridique, 29 (2) 473-493.

Emery, G. (1990). Lexical I ncongruence in Arabic-English translation. Babel 37(3), 129-137.

Farghal, M. and Shunnaq, A. (1992).MajorProblems in Legal Translation.Babel, 38 (4), pp. 203-210.

Faris, A., \&Sahu, R. (2013). The Translation of English Collocations into Arabic: Problems and Solutions. Journal of the College of Arts. 64, 51-66

Halliday, M. (1985/89) Part A. In M. A. K. Halliday and R. Hasan, Language, Context, and Text: Aspects of Language in a Social-Semiotic Perspective. Oxford/Geelong: OUP/Deakin University Press.

Halliday, M and Hasan, R. (1989). Language, Context, and Text: Aspects of Language in a Social Semiotic Perspective. Oxford: Oxford University Press.

Harvey, M. (2002). What's so special about Legal Translation? Meta: Journal des traducteurs Meta:/Translators 'Journal, 47(2), 177-185.

Langacker, W.( 1988). A View of Linguistic Semantics. In RUDZKA-OSTYN, B. (ed). Topics in Cognitive Linguistics.Amsterdam/Philadelphia : J. Benjamins, pp. 45-90.

Langacker, W.( 1997). The contextual basis of cognitive semantics. In NUYTS, J., PEDERSON, E. Language and Conceptualization. Cambridge: Cambridge University Press, pp.229-252.

Langacker, W. (2000).Grammar and Conceptualization. Berlin: Mouton De Gruyter. 
Mohammad, A; Alawi, N; \&Fakhouri, M. (2010). Translating Contracts between English and Arabic: Towards a More Pragmatic Outcome. Jordan Journal of Modern Languages and Literature, 2(1), 1-28.

Nemark, P.(1982).Approaches to Translation. Oxford: Pergamon.

Obenaus, G. ( 1995). The legal translator as information broker.(In Morris, M., ed. Translation and the law. Amsterdam: John Benjamins. p. 247-259.)

Rotman, E. (1995-1996). The inherent problems of legal translation: theoretical aspects. Indiana international \& comparative law review, 6(1), pp.187-196.

Sager J. (1993).Language Engineering and Translation: Consequences of Automation. Philadelphia: John Benjamin's Publishing Company.

Sager, J. (1998). Terminology: Theory. In Baker, M. (ed.). Routledge Encyclopedia of Translation Studies. London/New York :Routledge.

Šarčević, S. (1989).Conceptual Dictionaries for Translation in the Field of Law. International Journal of Lexicography, 2 (4), pp. 277-293.

Šarčević, S. (1997).New approach to legal translation: Kluwer Law International.

Šarčević, S. (2000).New Approach to Legal Translation. The Hague: Kluwer Law International.

Schwarz, H. (1977). Legal and administrative language.Babel, 23(1), pp.19-22.

Vermeer, J.( 1989a). Skopos und Translationsauftrag - Aufsätze. Heidelberg: Universität.

Wehmeier, S.(ed). Oxford Advanced Learners' Dictionary. (2005). As Hornby: Oxford University Press.

White, J. (1990). Justice as translation: an essay in cultural and legal criticism. Chicago: University of Chicago Press.

Wills,W.(1994).Translation as a Knowledge-Based Activity: Context, Culture, and Cognition. Language, Discourse and Translation in the West and Middle East.Amsterdam/Philadelphia: J. Benjamins, pp. 35-43. 
3318 (XXIX). Declaration on the Protection of Women and Children in Emergency and Armed Confict

The General Assembly,

Having considered the recommendation of the Economic and Social Council contained in its resolution 1861 (LVI) of $16 \mathrm{May} 1974$,

Expressing its deep concern over the sufferings of women and children belonging to the civilian population who in periods of emergency and armed conflict in the struggle for peace, self-determination, national liberation and independence are too of ten the victims of inhuman acts and consequently suffer serious harm,

Aware of the suffering of women and children in many areas of the world, especially in those areas subject to suppression, aggression, colonialism, racism, alien domination and foreign subjugation,

Deeply concerned by the fact that, despite general and unequivocal condemnation, colonialism, racism and alien and foreign domination continue to subject many peoples under their yoke, cruelly suppressing the national liberation movements and inflicting heavy losses and incalculable sufferings on the populations under their domination, including women and children,

Deploring the fact that grave attacks are still being made on fundamental freedoms and the dignity of the human person and that colonial and racist foreign domination Powers continue to violate international humanitarian law,

Recalling the relevant provisions contained in the instruments of international humanitarian law relative to the protection of women and children in time of peace and war,

Recalling, among other important documents, its resolutions 2444 (XXIII) of 19 December 1968, 2597

15 See Official Records of the United Nations Conference on Prescription (Limisarion) in the Insernational sale of Goods (United Nations publication, Sales No.: E.74.V.8), document A/CONF.63/15. 
(XXIV) of 16 December 1969 and 2674 (XXV) and 2675 (XXV) of 9 December 1970, on respect for human rights and on basic principles for the protection of civilian populations in armed conflicts, as well as Economic and Social Council resolution 1515 (XLVIII) of 28 May 1970 in which the Council requested the General Assembly to consider the possibility of drafting a declaration on the protection of women and children in emergency or wartime,

Conscious of its responsibility for the destiny of the rising generation and for the destiny of mothers, who play an important role in society, in the family and particularly in the upbringing of children,

Bearing in mind the need to provide special protection of women and children belonging to the civilian population,

Solemnly proclaims this Declaration on the Protection of Women and Children in Emergency and Armed Conflict and calls for the strict observance of the Declaration by all Member States: 